\title{
Short time antioxidant effect of sevoflurane and desflurane anesthesia, immediately before coronary artery bypass grafting
}

\section{Koroner arter baypas greft öncesinde sevofluran ve desfluranın kisa süreli antioksidan etkileri}

\author{
Büşra Tezcan*, Pınar Durak Uluer, Aslı Demir, Bahar Aydınl, Sevil Tokat, Mine \\ Taşlıpınar, Mustafa Atabey, Özcan Erdemli
}

Anesthesiology and Reanimation Clinic (B. Tezcan, MD, Assoc. Prof. P. D. Uluer, MD, A. Demir, MD, B. Aydınlı, MD, S. Tokat, MD, Assoc. Prof. Ö. Erdemli, MD), Türkiye Yüksek İhtisas Teaching and Research Hospital TR-06230 Ankara, Department of Biochemistry (M. Taşlıpınar, MD), Gazi University School of Medicine, TR-06560 Ankara, Department of General Surgery (M. Atabey, MD), Cumhuriyet University School of Medicine, TR-58140 Sivas

\begin{abstract}
Aim. Volatile anesthetics may represent a choice to attenuate oxidant effects. The aim of this study is to investigate the antioxidant status during sevoflurane and desflurane anesthesia immediately before coronary artery bypass graft surgery (CABG) with malondialdehyde (MDA), superoxide dismutase (SOD) and gluthation peroxidase (GPx). Methods. Forty patients, undergoing coronary artery bypass surgery, were enrolled in the study and randomized into two groups of 20 patients each. Anesthesia was maintained with $40 \%$ oxygen in air mixture, 1 minimum alveolar concentration (MAC) of desflurane in Group D and sevoflurane in Group S. Blood sampling for the measurements of MDA, SOD and GPx were performed at, T1-before anesthesia induction (baseline), T2-before surgical incision (about $20 \mathrm{~min}$ after T1), T3-before cardiopulmonary bypass (about 60 min after T2). Results. Plasma concentrations of MDA, SOD and GPx levels increased significantly during T2 and T3 periods as compared with the baseline values in both groups. This increase was greater in group D versus group S. Conclusion. We conclude that desflurane may cause more systemic lipid peroxidation than sevoflurane during immediately before CABG.
\end{abstract}

Keywords: Cardiac anesthesia, desflurane, sevoflurane, oxidative stress, antioxidant effect

\section{Özet}

Amaç. Volatil anestezikler oksidan etkiyi zayıflatabilirler. Bu çalışmanın amacı koroner arter bypass greft ameliyatının hemen öncesinde malondialdehit (MDA), süperoksit dismutaz (SOD) ve glutatyon peroksidaz (GPx) ile sevofluran ve desfluranın antioksidan etkisinin araştırılmasıdır. Yöntemler. Koroner arter baypas greft ameliyatı geçirecek 40 hasta çalışmaya alındı, hastalar rastgele 20'şer kişilik iki gruba ayrıldı. Anestezi \%40 oksijen ile hava karışımı yanında Grup D'de $1 \mathrm{MAC}$ desfluran, Grup S'de 1MAC sevofluran ile sürdürüldü. MDA, SOD ve GPx için kan örnekleri; T1; anestezi indüksiyonundan önce (bazal), T2; cerrahi insizyondan önce (yaklaşık T1den 20 dk sonra), T3; kardiyopulmoner baypastan önce (yaklaşık T2 den 60 dk sonra) alınd1. Bulgular. Bazal değerlere göre her iki grupta MDA, SOD ve GPx değerleri T2 ve T3 zamanlarında anlamlı artış gösterdi. Grup D için bu artış Grup S'den daha fazlaydı. Sonuç. Koroner arter baypas greft ameliyatının hemen öncesinde desfluran, sevoflurandan daha fazla sistemik lipid peroksidasyonuna neden olur sonucuna vardık.

Anahtar sözcükler: Kardiyak anestezi, desfluran, sevofluran, oxidatif stres, antioxidan etki

Geliş tarihi/Received: May 10, 2012; Kabul tarihi/Accepted: October 12, 2012

\section{*Corresponding author:}

Dr. Büşra Tezcan, Anestezi ve Reanimasyon Kliniği, Türkiye Yüksek İhtisas Eğitim ve Araştırma Hastanesi, TR-06230 Ankara. E-mail: busraytezcan@yahoo.com 


\section{Introduction}

Under normal conditions, in the human body a partially reduced forms of oxygen, including active oxygen, superoxide anion, hydrogen peroxide and hydroxyl radical are produced [1]. These oxygen species (ROS) are highly reactive and initially they attack cellular components like lipids, proteins and deoxyribonucleic acid [2]. On the other hand, human body has many enzymatic and non enzymatic antioxidative systems [3]. Many stress factors (anesthesia, surgery, extracorporeal circulation etc.) may change prooxidant/anti-oxidant balance. Volatile anesthetics are used for patients undergoing coronary artery bypass grafting $(\mathrm{CABG})$ due to their reducing effect on periprocedural oxidative stress. This potential benefits led to a renewed interest in antioxidant effects of volatile anesthetics $[4,5]$. To our knowledge, no study has evaluated the short time antioxidant effects of frequently used volatile anesthetics such as desflurane and sevoflurane. In our study, we tried to demonstrate how oxidative stress parameters differs between desflurane and sevoflurane groups. We took blood samples before anesthesia induction, before surgical incision and before cardiopulmonary bypass. To evaluate antioxidant status; MDA, which is an intermediate product of lipid peroxidation, SOD and GPx which catalyze the conversion of ROS into less active species were used [6].

\section{Material and methods}

Between May 2009-June 2009, 40 patients who underwent CABG surgery at our institution, aged 37-73 years, in American Society of Anesthesiologists physical status II or III were enrolled in the study and single-blind randomized into two groups of 20 patients each. First group (Group D) consisted of patients who have received desflurane and the other group (Group S) consisted of those who received sevoflurane. Exclusion criteria included patients who have left ventricular ejection fraction lower than $40 \%$, and those with diabetes mellitus. None of the patients had a history of smoking or prior or current use of antioxidants. The patients were not premedicated. Preoperatively, routine 12-lead electrocardiograms, pulse oximetry and invasive arterial pressure monitoring were obtained for all patients. Institutional Ethics Committee approved the study protocol and all patients gave written informed consent to participate in the study. All patients received the same anesthetic induction with $10 \mu / \mathrm{kg}$ fentanyl, $0.1 \mathrm{mg} / \mathrm{kg}$ midazolam and $0.1 \mathrm{mg} / \mathrm{kg}$ pancuronium. The patients were ventilated in a volume controlled mode with a frequency of $12-14$ breaths $/ \mathrm{min}$ and a tidal volume of $8-10 \mathrm{~mL} / \mathrm{kg}$ to maintain the endtidal $\mathrm{CO} 2$ between 35 and $40 \mathrm{mmHg}$. A right internal jugular venous catheter was inserted after induction of anesthesia. Anesthesia was maintained with $40 \%$ oxygen in air mixture, 1 minimum alveolar concentration (MAC) of desflurane in Group D and sevoflurane in Group S. Blood samples were obtained from arterial cannula for the measurement of MDA, SOD and GPx. Blood sampling for the measurement of MDA, SOD and GPx were performed at: T1-before anesthesia induction (baseline), T2-before surgical incision (about 20 min after T1) includes induction, entubation and jugulary venous catheterization period, T3-before CPB (about $60 \mathrm{~min}$ after T2) includes sternotomy, LIMA extraction and cannulation period. Samples were centrifuged (1500 $\mathrm{rpm}$ ) within $10 \mathrm{~min}$ and the supernatants were stored at $-70^{\circ} \mathrm{C}$ until analysis within 2 weeks. Prior to cannulation for the institution of CPB, 300-400 U/kg heparin sulphate was administered to raise the activated clotting time to at least $450 \mathrm{sec}$. Blood electrolytes, glucose and osmolality were monitored and maintained within normal ranges.

\section{Determination of lipid peroxidation}

The thiobarbituric acid assay, which measures MDA, is the most commonly used method for estimating lipid peroxidation. MDA reacts with thiobarbituric acid to form a colored complex. Thiobarbituric acid reactive substances were determined using the method described by Yoshioka et al. [7]. For analysis, $0.5 \mathrm{~mL}$ plasma, $2.5 \mathrm{~mL}$ trichloroacetic acid $(200 \mathrm{~g} / \mathrm{L})$ and $1 \mathrm{~mL}$ thiobarbituric acid $(6.7 \mathrm{~g} / \mathrm{L})$ were mixed and boiled for $30 \mathrm{~min}$. Two 
milliliters of butanol was added to tubes and the colored phase was extracted by centrifugation at $3000 \mathrm{rpm}$. Absorption of the butanol phase was determined spectrophotometrically at $532 \mathrm{~nm}$ wavelength. Thiobarbituric acid reactive substances were expressed as nanomol of MDA per milliliter of plasma $(\mathrm{nmol} / \mathrm{mL})$. The measurements were not corrected with respect to the hemodilution. Determination of antioxidant enzymes SOD activity was measured kinetically by a method described by Sun et al. [8]. The principle of the method is based on the inhibition of nitroblue tetrazolium reduction by the xanthine-xanthine oxidase system as a superoxide generator. SOD activity was expressed as units per mol (U/mol). GPx activity was measured by a method described by Paglia et al. [9]. GPx catalyses the oxidation of glutathione. In the presence of glutathione reductase and reduced nicotinamide adenine dinucleotide phosphate (NADPH) oxidized glutathione is converted to the reduced form with a concomitant oxidation of reduced NADPH to NADP. GPx activity was measured by the decrease of reduced NADPH absorbance at $340 \mathrm{~nm}$ and expressed as nanomol per milliliter of plasma $(\mathrm{nmol} / \mathrm{min} / \mathrm{mL})$.

\section{Statistically analysis}

The data were recorded on a computer with SPSS for Windows 10.1 statistically software (SPSS Inc., Chicago, IL, USA). Data were expressed as the median (min-max). Medians were compared using Mann - Whitney U Test. Friedman Test was used for repeated measurements within the groups with Bonferroni post hoc analysis. Since the basal measurements were different statistically, covariance analysis were used for comparison between groups Statistical significance was set at $\mathrm{p}<0.05$.

\section{Results}

There were no significant differences between two groups regarding of age, gender and weight (Table 1). In desflurane group; patients' baseline measurements of MDA, GPx and SOD were statistically higher than sevoflurane group. In group $\mathrm{D}$, plasma concentrations of MDA median (min-max) increased significantly in at T2 (7.2) and T3 (8.8) $\mathrm{nmol} / \mathrm{mL}$ respectively, compared with the baseline value $6.2 \mathrm{nmol} / \mathrm{mL}(\mathrm{p}<0.001)$. In group S, significantly increased levels of MDA median (min-max) were observed at T2 values $5.9 \mathrm{nmol} / \mathrm{mL}$, T3 values $6.6 \mathrm{nmol} / \mathrm{mL}$, compared with the baseline value 5.0 $\mathrm{nmol} / \mathrm{mL}(\mathrm{p}<0.001)$. In Group D (Figure 1), plasma concentrations of SOD median (minmax) increased significantly in at T2 (25.2) and T3 (28) U/mol respectively, compared with the baseline value $23.4 \mathrm{U} / \mathrm{mol}(\mathrm{p}<0.001)$. In group $\mathrm{S}$, significantly increased levels of SOD median (min-max) were observed a T2 values $17 \mathrm{U} / \mathrm{mol}$, T3 values $16.7 \mathrm{U} / \mathrm{mol}$, compared with the baseline value $15.6 \mathrm{U} / \mathrm{mol}(\mathrm{p}<0.001)$. In Group D (Figure 2), plasma concentrations of GPx median (min-max) increased significantly at T2 (124.6) and T3 (131.8) $\mathrm{nmol} / \mathrm{min} / \mathrm{mL}$ respectively, compared with the baseline value $120.7 \mathrm{nmol} / \mathrm{min} / \mathrm{mL}$ $(\mathrm{p}<0.001)$ In group $\mathrm{S}$, significantly increased levels of GPx median (min-max) were observed a T2 values $112 \mathrm{nmol} / \mathrm{min} / \mathrm{mL}$, T3 values $114 \mathrm{nmol} / \mathrm{min} / \mathrm{mL}$ compared with the baseline value $110.8 \mathrm{nmol} / \mathrm{min} / \mathrm{mL}(\mathrm{p}<0.001)$ (Figure 3). On the other hand, in desflurane group, for all measured parameters, the amount of increase from T1 to T3 was found to be significantly higher as compared with the sevoflurane group (for MDA $p<0.003$, for SOD $\mathrm{p}<0.004$, and for GPx $\mathrm{p}<0.001$ ).

Table 1. Patient characteristics data are mean \pm SD or number of patients.

\begin{tabular}{lll}
\hline & Group D & Group S \\
\hline Age (yr) & $59 \pm 9(40-73)$ & $54 \pm 10(37-72)$ \\
Weight (kg) & $72 \pm 8(55-88)$ & $72 \pm 10(46-94)$ \\
Gender ratio (F/M) & $3 / 17$ & $5 / 15$ \\
\hline
\end{tabular}




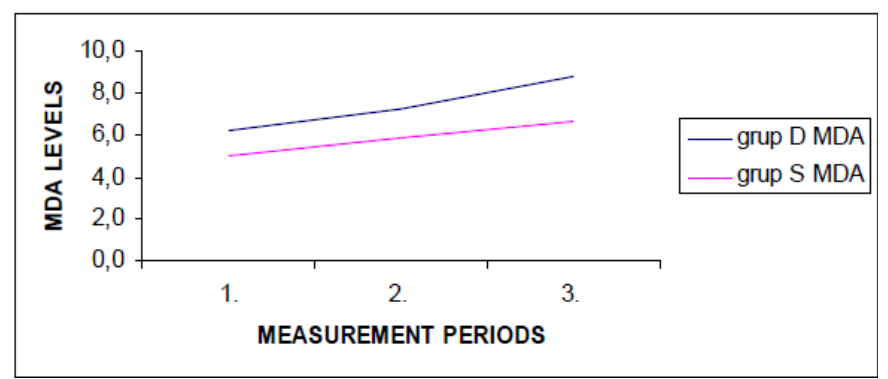

Figure 1. MDA levels.

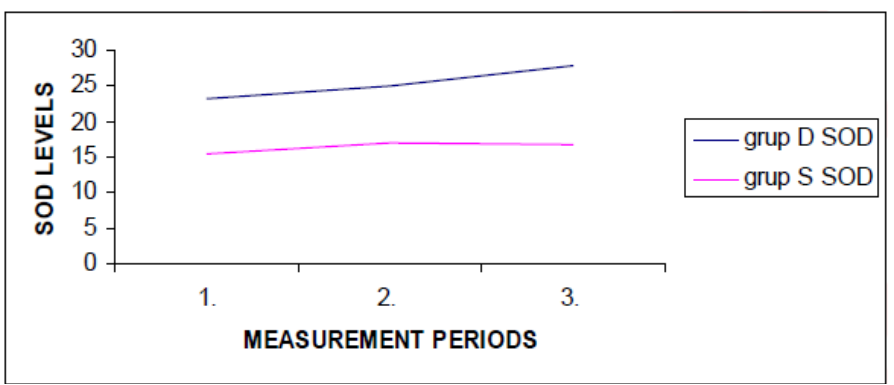

Figure 2. SOD levels.

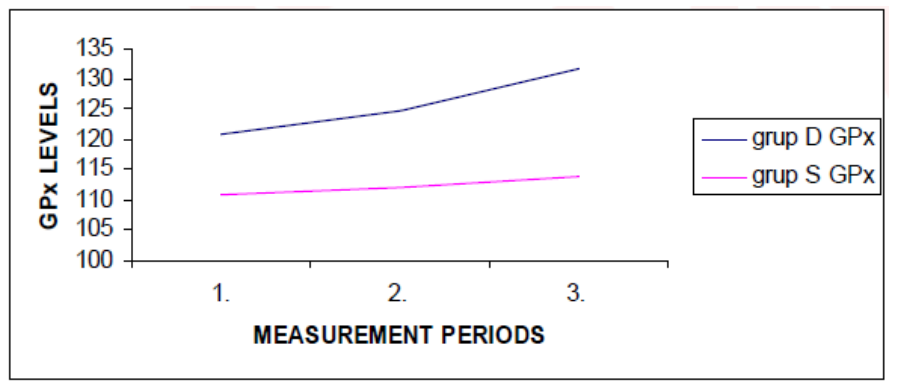

Figure 3. GPX levels.

\section{Discussion}

Free radicals are considered as factors responsible for systemic inflammation, one of the most significant harmful consequences of cardiopulmonary bypass (CPB) and may contribute to the development of several postoperative complications [10]. They have been implicated in reversible postischaemic contractile dysfunction, cardiac cell death, dysrhythmias and other various cardiovascular disease processes. Brief exposure of the heart to a volatile anesthetic has been shown to induce a state of protection against the effects of ischaemia reperfusion injury in animal model. Sevoflurane mimics ischaemic preconditioning with an improvement of postischaemic contractility in isolated guinea pig hearts [11]. There is also evidence of its occurrence in humans. Belhomme et al. [12] reported that brief pretreatment with izoflurane decreased cardiac enzyme release in patients undergoing CABG. We investigated that if the reported favourable cardiovascular effects of volatiles were clinically relevant, which volatile anesthetics (desflurane or sevoflurane) shift the oxidative balance during pre-cardiopulmonary bypass period. To study this question, we compared antioxidant status of two groups of coronary surgery patients in whom the only short time exposure to either sevoflurane or desflurane as volatile anesthetics in the anesthetic procedure. In our study, basal levels of MDA, SOD and GPx were found to be significantly different between groups. Differences that can not be randomized like genetic specifities, nutrition habits, 
medications, geographic habitat seems to cause these variances. However, MDA, SOD and GPx were found to be significantly increased in both groups as compared with the baseline measurements. In desflurane group the rate of increase was significantly higher as compared with the sevoflurane group. Gonenc et al. [13] have reported that after anesthesia induction, no significant change was detected in levels of MDA, SOD and GPx, however, all these parameters were found to be increased after ischaemia commenced due to cross clamping. Ochoa et al. [10] have shown that SOD and GPx values were significantly increased after sternotomy as compared the baseline values before CABG surgery. In a study of Koksal et al. [1], MDA levels were shown to be significantly increased in patients undergoing laparoscopic cholecystectomy surgery after sevoflurane and desflurane anesthesia; with a greater increase with desflurane as compared to sevoflurane. Also, in a similar study conducted in patients who underwent laparoscopic surgery with same volatile anesthetethic agents, Sivac1 et al. [14] detected significant increase in MDA levels at postoperative 6 and 24 hours with desflurane. As it is seen many studies have evaluated the stress response of body as a change in oxidativeantioxidative balance. These studies examined different periods of the operation. In our study, short time effects of sevoflurane and desflurane anesthesia on oxidative status have been investigated, during immediately before cardiopulmonary bypass period.

In accordance with the previous studies, we found that MDA, SOD and GPx were found to be more significantly increased after exposure to desflurane. We conclude that desflurane may cause more systemic lipid peroxidation than sevoflurane during immediately before.

\section{References}

1. Koksal GM, Sayılgan C, Aydın S, Uzun H, Oz H. The effects of sevoflurane and desflurane on lipid peroxidation during laparoscopic cholecystectomy. Eur J Anaesthesiol 2004; 21: 217-20.

2. Hanley PJ, Ray J, Brandt U, Daut J. Halothane, isoflurane and sevoflurane inhibit NADH:ubiquinone oxidoreductase (complex I) of cardiac mitochondria. J Physiol 2002; 544: 687-93.

3. Pechan I, Olejarova I, Danova K, Fischer V, Minarova H, Dobisova A, Halcak L, Rendekova V, Gabauer I. Antioxidant status of patients after on-pump and offpump coronary artery bypass grafting. Bratisl Lek Listy 2004; 105: 45-50.

4. Dikmen B, Unal Y, Pampal HK, Nurlu N, Kurtipek O, Canbolat O, Ozoğul C, Kavutcu M. Effects of repeated desflurane and sevoflurane anesthesia on enzymatic free radical scavanger system. Mol Cell Biochem 2007; 294: 31-6.

5. Hu G, Vasiliauskas T, Salem MR, Rhone DP, Crystal GJ. Neutrophils pretreated with volatile anesthetics lose ability to cause cardiac dysfunction. Anesthesiology 2003; 98: 712-8.

6. Turan R, Yagmurdur H, Kavutcu M, Dikmen B. Propofol and tourniquet induced ischaemia reperfusion injury in lower extremity operations. Eur J Anaesthesiol 2007; 24: 185-9.

7. Yoshioka T, Kawada K, Shimada T, Mori M. Lipid peroxidation in maternal and cord blood and protective mechanism against activated-oxygen toxicity in the blood. Am J Obstet Gynecol 1979; 135: 372-6.

8. Sun Y, Oberley LW, Li Y. A simple method for clinical assay of superoxide dismutase. Clin Chem 1988; 34: 497-500.

9. Paglia DE, Valentine WN. Studies on the quantitative and qualitative characterization of erythrocyte glutathione peroxidase. J Lab Clin Med 1967; 70: 158-69.

10. Ochoa JJ, Vilchez MJ, Mataix J, Ibáñez-Quiles S, Palacios MA, Muñoz-Hoyos A. Oxidative stress in patients undergoing cardiac surgery: comparative study of revascularization and valve replacement procedures. J Surg Res 2003; 111: 24854. 
11. Kevin LG, Novalija E, Stowe DF. Reactive oxygen species as mediators of cardiac injury and protection: The relevance to anesthesia practice. Anesth Analg 2005; 101: 1275-87.

12. Belhomme D, Peynet J, Louzy M, Launay JM, Kitakaze M, Menasché P. Evidence for preconditioning by isoflurane in coronary artery bypass graft surgery. Circulation 1999; 100: II340-4.

13. Gönenç A, Hacişevki A, Bakkaloğlu B, Soyağir A, Torun M, Karagöz H, Simşek B. Oxidative stress is decreased in off-pump versus on-pump coronary artery surgery. J Biochem Mol Biol 2006; 39: 377-82.

14. Sivaci R, Kahraman A, Serteser M, Sahin DA, Dilek ON. Cytotoxic effects of volatile anesthetics with free radicals undergoing laparoscopic surgery. Clin Biochem 2006; 39: 293-8. 